\title{
Author Correction: The ASIC3/P2X3 cognate receptor is a pain-relevant and ligand-gated cationic channel
}

Gabriele Stephan ${ }^{1}$, Lumei Huang ${ }^{1,2}$, Yong Tang ${ }^{2}$, Sandra Vilotti ${ }^{3}$, Elsa Fabbretti ${ }^{4}, Y_{e}$ Yu $^{5}$, Wolfgang Nörenberg ${ }^{1}$, Heike Franke ${ }^{1}$, Flóra Gölöncsér ${ }^{6,7}$, Beáta Sperlágh ${ }^{6}$, Anke Dopychai ${ }^{8}$, Ralf Hausmann ${ }^{8}$, Günther Schmalzing ${ }^{8}$, Patrizia Rubini ${ }^{1} \&$ Peter $\|^{1}$ les $^{1}$

Correction to: Nature Communications https://doi.org/10.1038/s41467-018-03728-5; published online: 10 April 2018

The originally published version of this article contained an error in the name of the author Flóra Gölöncsér, which was incorrectly given as Flóra Göröncsér. This has now been corrected in both the PDF and HTML versions of the article.

Published online: 17 August 2018

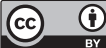

Open Access This article is licensed under a Creative Commons Attribution 4.0 International License, which permits use, sharing, adaptation, distribution and reproduction in any medium or format, as long as you give appropriate credit to the original author(s) and the source, provide a link to the Creative Commons license, and indicate if changes were made. The images or other third party material in this article are included in the article's Creative Commons license, unless indicated otherwise in a credit line to the material. If material is not included in the article's Creative Commons license and your intended use is not permitted by statutory regulation or exceeds the permitted use, you will need to obtain permission directly from the copyright holder. To view a copy of this license, visit http://creativecommons.org/licenses/by/4.0/.

(C) The Author(s) 2018

\footnotetext{
${ }^{1}$ Rudolf-Boehm-Institut für Pharmakologie und Toxikologie, University of Leipzig, Leipzig 04107, Germany. ${ }^{2}$ Acupuncture and Tuina School, Chengdu University of Traditional Chinese Medicine, Chengdu 610075, China. ${ }^{3}$ Neurobiology Sector, International School for Advanced Studies, Trieste 34136, Italy. ${ }^{4}$ Department of Life Sciences, University of Trieste, Trieste 34127, Italy. ${ }^{5}$ Institute of Neuroscience and State Key Laboratory of Neuroscience, Shanghai 100025, China. ${ }^{6}$ Laboratory of Molecular Pharmacology, Institute of Experimental Medicine, Hungarian Academy of Sciences, Budapest 1043, Hungary. 7 János Szentágothai School of Neurosciences, Semmelweis University School of PhD Studies, Budapest 1043, Hungary. ${ }^{8}$ Molecular Pharmacology, Rheinisch-Westfälische Technische Hochschule (RWTH) Aachen University, Aachen 52072, Germany. Correspondence and requests for materials should be addressed to P.I. (email: peter.illes@medizin.uni-leipzig.de)
} 